\title{
Deceleration by angiotensin II of the differentiation and bone formation of rat calvarial osteoblastic cells
}

\author{
H Hagiwara, Y Hiruma, A Inoue, A Yamaguchi ${ }^{\mathbf{1}}$ and $\mathbf{S}$ Hirose $^{\mathbf{2}}$ \\ Research Center for Experimental Biology, Tokyo Institute of Technology, 4259 Nagatsuta-cho, Midori-ku, Yokohama 226, Japan, ${ }^{1}$ Department of Oral \\ Pathology, School of Dentistry, Showa University, Hatanodai, Tokyo 142, Japan and ${ }^{2}$ Department of Biological Sciences, Tokyo Institute of Technology, \\ 4259 Nagatsuta-cho, Midori-ku, Yokohama 226, Japan \\ (Requests for offprints should be addressed to H Hagiwara, Research Center for Experimental Biology, Tokyo Institute of Technology, 4259 Nagatsuta-cho, \\ Midori-ku, Yokohama 226, Japan)
}

\begin{abstract}
We examined the effects of angiotensin II (Ang II) on the differentiation of rat calvarial osteoblastic cells and on the formation of bone by these cells. Northern blotting analysis revealed that Ang II inhibited the expression of mRNA for osteocalcin, which is a protein that is specifically expressed during maturation of osteoblastic cells. Ang II decreased the activity of alkaline phosphatase, a marker of osteoblastic differentiation, in the cells, acting via the type $1\left(\mathrm{AT}_{1}\right)$ receptor. We used von Kossa staining to examine the formation of mineralized nodules by osteoblastic cells. Both the number and the total area of mineralized nodules
\end{abstract}

were quantified and shown to be decreased by $10^{-7} \mathrm{M}$ Ang II. The accumulation of calcium in cells and the matrix layer was also decreased by Ang II. Binding analysis with subtype-specific antagonists revealed the presence of $\mathrm{AT}_{1}$ receptors for Ang II in this culture system. Ang II caused a marked increase in the rate of production of intracellular cAMP in this system. Our data suggest that Ang II might be intimately involved in osteoblastic metabolism through its interaction with the $\mathrm{AT}_{1}$ receptor. Journal of Endocrinology (1998) 156, 543-550

\section{Introduction}

Bone morphogenetic protein (Yamaguchi et al. 1991), glucocorticoid (Bellows et al. 1990, Wong et al. 1990), and growth factors, such as transforming growth factor $\beta$ (Antosz et al. 1989, Harris et al. 1994), basic fibroblast growth factor (Deng et al. 1996), and insulin-like growth factor-I (Baker et al. 1993, Liu et al. 1993), have been shown to modulate differentiation-related events in cultures of osteoblastic cells. In previous studies, we demonstrated that 8-bromo cyclic AMP (8-Br-cAMP) and 8-bromo cyclic GMP (8-Br-cGMP) act reciprocally to regulate the differentiation of osteoblastic cells and the mineralization process (Inoue et al. 1995). We showed that 8-Br-cAMP inhibited the differentiation of osteoblastic cells and 8-Br-cGMP stimulated this process. Natriuretic peptides are physiological agonists that activate receptor guanylate cyclases with the resultant synthesis of the second messenger cGMP. Therefore, we postulated that natriuretic peptides might be involved in osteoblastic metabolism. We found that, indeed, natriuretic peptides did promote bone formation via the action of cGMP in a signal-transduction pathway that was mediated by receptor guanylate cyclases in osteoblastic cells (Hagiwara et al. 1996) and clonal in osteoblastic MC3T3-E1 cells (Inoue et al. 1996). In the present study, we investigated the effects of angiotensin II (Ang II), which induces the synthesis of intracellular cAMP, on osteoblastic metabolism using osteoblastic cells derived from rat calvariae.

Ang II, a bioactive octapeptide, plays a major role in the maintenance of extracellular fluid volume and blood pressure. In addition to its well-established role in circulatory homeostasis, it has been implicated in a variety of processes, which include the control of nervous system activity (Phillips 1987, Steckelings et al. 1992), cell growth (Aceto \& Baker 1990), and several developmental processes (Millan et al. 1991, Steckelings et al. 1992). Pharmacological studies have shown that there are two different types of Ang II receptor, the type $1\left(\mathrm{AT}_{1}\right)$ receptor and the type $2\left(\mathrm{AT}_{2}\right)$ receptor. It has been reported that the $\mathrm{AT}_{1}$ receptor regulates two distinct signaling pathways that involve $\mathrm{G}$ protein(s). One pathway involves activation of phospholipase $\mathrm{C}$, with subsequent stimulation of the production of inositol 1,4,5trisphosphate, and the other involves the regulation of the level of cAMP via the activation or inhibition of adenylate cyclase. The signaling pathway of $\mathrm{AT}_{2}$ receptors remains to be elucidated. Ang II is generated from Ang I by angiotensin-converting enzyme (ACE). Inhibitors of ACE, such as captopril and enalapril, have been successfully used in the treatment of patients with hypertension. However, exposure to ACE inhibitors was reported to 
have resulted in an aborted fetus in which no skull tissue had formed above the brain tissue (Mehta \& Modt 1989, Barr \& Cohen 1991). Thus, the use of ACE inhibitors during pregnancy has been associated with high risk of hypocalvaria or acalvaria in the fetus.

The purpose of our present study was to elucidate the contribution of Ang II to osteoblastic metabolism using cultured cells from calvariae of newborn rats. In this culture system, the process of bone formation mimics that observed in vivo and mineralized nodules are formed that have the characteristics of woven bone (Antosz et al. 1989, Wong et al. 1990, Harris et al. 1994, Hagiwara et al. 1996). Also, this culture system does not require the specific reagents (e.g. dexamethasone and bone morphogenetic proteins) which bone marrow stromal and most osteoblastic lineages need for mineralization. We found evidence in the present study to suggest that Ang II might decelerate osteoblastic differentiation and the formation of bone by osteoblastic cells.

\section{Materials and Methods}

\section{Materials}

Rat Ang II was purchased from the Peptide Institute, Osaka, Japan. DuP 753 (a specific antagonist of $\mathrm{AT}_{1}$ receptors) and PD-123319 (a specific antagonist of $\mathrm{AT}_{2}$ receptors) were generous gifts from DuPont/Merck (Wilmington, DE, USA) and Dr Hitoshi Miyazaki (Tsukuba University, Japan) respectively. ${ }^{32} \mathrm{P}$-Labeled nucleotides and ${ }^{125} \mathrm{I}$-Ang II $(74 \mathrm{TBq} / \mathrm{mmol})$ were obtained from Amersham Life Science (Bucks, UK). $\alpha$-Modified minimum essential medium ( $\alpha$-MEM), penicillin/streptomycin antibiotic mixture, and fetal bovine serum were obtained from Life Technologies, Inc. (Grand Island, NY, USA).

\section{Isolation and culture of cells}

Cells were isolated enzymatically from calvariae of newborn Sprague-Dawley rats as described previously (Hagiwara et al. 1996). Fourteen calvariae were dissected out and all adhering soft tissue was removed. The calvariae were cut into pieces and subjected to six sequential 20-min digestions (yielding digests 1 through 6) with $3 \mathrm{ml}$ of an enzyme mixture that contained $1 \mathrm{mg} / \mathrm{ml}$ collagenase (150-250 units/mg; Wako Pure Chemical Industries, Osaka, Japan) and $0.5 \mathrm{mg} / \mathrm{ml}$ trypsin (Sigma, St Louis, MO, USA). Cells from a pool of digests 4,5 , and 6 were plated in $75 \mathrm{~cm}^{2}$ dishes and grown in $\alpha$-MEM supplemented with $10 \%$ fetal bovine serum, 100 units $/ \mathrm{ml}$ penicillin, and $100 \mu \mathrm{g} / \mathrm{ml}$ streptomycin in a humidified atmosphere of $5 \% \mathrm{CO}_{2}$ in air at $37^{\circ} \mathrm{C}$. Cell populations enriched for osteoblastic cells (digests 4 through 6) were obtained by the sequential collagenase digestions. The medium was replaced by fresh medium after $24 \mathrm{~h}$. After reaching confluence, the cells were detached by treatment with $0.05 \%$ trypsin and cells from three dishes (digests 4 , 5 , and 6) were combined. The cells were replated in 12 -well plates $\left(3.8 \mathrm{~cm}^{2} /\right.$ well $)$ at a density of $1 \times 10^{4}$ cells $/ \mathrm{cm}^{2}$ and grown in $\alpha$-MEM supplemented with $10 \%$ fetal bovine serum, 100 units $/ \mathrm{ml}$ penicillin, $100 \mu \mathrm{g} / \mathrm{ml}$ streptomycin, $5 \mathrm{mM} \beta$-glycerophosphate, and $50 \mu \mathrm{g} / \mathrm{ml}$ ascorbic acid. During subculture, the medium was replaced every 4 days and Ang II and/or its analog were added every 2 days.

We reported previously that in our culture system the expression of alkaline phosphatase (ALPase) activity and of mRNA for osteocalcin is upregulated at day 9 and day 14 respectively, and the formation of mineralized nodules was also observed at day 14 (Hagiwara et al. 1996). Therefore, we used these time points for assay in these experiments.

\section{Northern blotting analysis}

RNA was extracted from cultured osteoblastic cells derived from rat calvariae by the acid guanidiniumphenol-chloroform method (Chomczynski \& Sacchi 1987). Total RNA $(20 \mu \mathrm{g})$ was subjected to electrophoresis on a $1 \%$ agarose gel that contained $2 \cdot 2 \mathrm{M}$ formaldehyde and was then transferred to a MagnaGraph nylon membrane (Micron Separations Inc., Westborough, MA, USA). After baking of the membrane, the RNA on the membrane was allowed to hybridize overnight with cDNA for osteocalcin (Yamaguchi et al. 1991) or for $\beta$-tubulin at $42{ }^{\circ} \mathrm{C}$ in $50 \%$ formamide that contained $5 \times \operatorname{SSPE}\left(1 \times \operatorname{SSPE}\right.$ is $0.15 \mathrm{M} \mathrm{NaCl}, 15 \mathrm{mM} \mathrm{NaH}_{2} \mathrm{PO}_{4}$, $\mathrm{pH} 7 \cdot 0,1 \mathrm{mM}$ EDTA), $2 \times$ Denhardt's solution $(0 \cdot 1 \%$ each of BSA, polyvinylpyrrolidone, and Ficoll), 1\% SDS and $100 \mu \mathrm{g} / \mathrm{ml}$ herring sperm DNA. Each cDNA probe was radiolabeled with a Random Primer DNA Labeling Kit (Takara, Shiga, Japan). The membrane was washed twice in $1 \times \operatorname{SSC}(0.15 \mathrm{M} \mathrm{NaCl}, 15 \mathrm{mM}$ sodium citrate, $\mathrm{pH} 7 \cdot 0$ ) that contained $0 \cdot 1 \%$ SDS at room temperature for $5 \mathrm{~min}$ each and twice in $1 \times \mathrm{SSC}$ that contained $0 \cdot 1 \%$ SDS at $55^{\circ} \mathrm{C}$ for $1 \mathrm{~h}$ each and then it was exposed to an imaging plate for $4 \mathrm{~h}$. The plate was analyzed with a Bioimage Analyzer (BAS 2000; Fuji Film, Tokyo, Japan).

\section{Assay of ALPase activity}

Cells were subcultured in $\alpha$-MEM that contained $10 \%$ fetal bovine serum, $5 \mathrm{mM} \beta$-glycerophosphate, $50 \mu \mathrm{g} / \mathrm{ml}$ ascorbic acid, and various test compounds. The cells were washed twice with $50 \mathrm{mM}$ Tris- $\mathrm{HCl}, \mathrm{pH} 7 \cdot 2$, and sonicated in $1 \mathrm{ml} 50 \mathrm{mM}$ Tris- $\mathrm{HCl}, \mathrm{pH} 7 \cdot 2$, that contained $0 \cdot 1 \%$ Triton $\mathrm{X}-100$ and $2 \mathrm{mM} \mathrm{MgCl}$ for $15 \mathrm{~s}$ with a sonicator (Ultrasonic Disruptor UD-201; Tomy Co., Tokyo, Japan). The ALPase activity of the sonicate was determined by an established technique with $p$-nitrophenyl phosphate as the substrate (Lowry et al. 
1954). Concentrations of protein were determined with BCA protein assay reagent (Pierce Chemical Co., Rockford, IL, USA).

\section{von Kossa staining}

Osteoblastic cells in 12-well plates were fixed with $10 \%$ formaldehyde for $30 \mathrm{~min}$ and washed three times with $10 \mathrm{mM}$ Tris-HCl, $\mathrm{pH} 7 \cdot 2$. The fixed cells were incubated with $5 \%$ silver nitrate for $5 \mathrm{~min}$ in sunlight, washed twice with water, and then treated with 5\% sodium thiosulfate (Hagiwara et al. 1996). Mineralized nodules were assessed with respect to their number and the total area of nodules using an automated imaging system, which consisted of a BH microscope (Olympus), a camera (CCD/ICD-740, Olympus) and Mac SCOPE program (Mitani Corp., Fukui, Japan).

\section{Quantification of calcium}

Mineralized nodules from 1 well of a 12-well plate were washed twice with PBS, incubated overnight in $1 \mathrm{ml}$ $0.5 \mathrm{M} \mathrm{HCl}$ with gentle shaking and sonicated for $15 \mathrm{~s}$ with the sonicator (Ultrasonic Disruptor UD-201). The calcium in the sonicate was quantified by the o-cresolphthalein complexone method with a Calcium C-Test Wako (Wako Pure Chemical Industries) (Hagiwara et al. 1996).

\section{Assay of binding of ${ }^{125} \mathrm{I}-\mathrm{Ang}$ II}

Cells, grown in 12 -well plates $\left(3.8 \mathrm{~cm}^{2} /\right.$ well), were washed twice with PBS $(\mathrm{pH} 7 \cdot 3 ; 20 \mathrm{mM}$ potassium phosphate, $130 \mathrm{mM} \mathrm{NaCl}$, and $1 \mathrm{mM}$ EDTA) and incubated in $0.5 \mathrm{ml}$ of PBS that contained $0.2 \%(\mathrm{w} / \mathrm{v})$ BSA (fraction V; Sigma), ${ }^{125}$ I-labeled Ang II (920 Bq/well), and an unlabeled analog of Ang II at various concentrations for $1 \mathrm{~h}$ at $4{ }^{\circ} \mathrm{C}$. After incubation, cells were washed twice with ice-cold PBS and solubilized with $0.5 \mathrm{ml} 0.1 \mathrm{M}$ $\mathrm{NaOH}$. The radioactivity was measured with a gamma counter (ARC-300; Aloka, Tokyo, Japan).

\section{Measurement of the accumulation of intracellular cAMP}

Cells, grown in 12 -well plates, were incubated at $37^{\circ} \mathrm{C}$ for 15 min with serum-free $\alpha$-MEM that had been supplemented with $0.5 \mathrm{mM}$ 3-isobutyl-1-methylxanthine after two washes with serum-free $\alpha$-MEM. Osteoblastic cells were subsequently incubated at $37^{\circ} \mathrm{C}$ for $15 \mathrm{~min}$ with Ang II and/or its analog. After incubation, the cells were lysed by addition of $200 \mu \mathrm{l}$ of a $0 \cdot 1 \mathrm{M}$ solution of $\mathrm{HCl}$ that contained $5 \mathrm{mM}$ EDTA. The amount of cAMP in each cell lysate was measured with an RIA kit from Yamasa (Chiba, Japan).

\section{Results}

\section{Northern blotting analysis of $m R N A$ for osteocalcin}

To determine whether Ang II is involved in osteoblastic maturation, we performed Northern blotting analysis using cDNA for osteocalcin, a protein that is a marker of osteoblastic maturation, as the probe. Ang II decreased the steady-state level of expression of the mRNA for osteocalcin in cells that had been treated with Ang II for 14 days (Fig. 1). There were no appreciable changes in the level of mRNA for $\beta$-tubulin in cells assayed similarly on the same respective days. These results suggest that Ang II might regulate the maturation of osteoblastic cells in our culture system.

\section{Reduction of ALPase activity by Ang II}

We measured the activity of ALPase on day 9 after the start of the continuous culture of cells in the presence and in the absence (control) of Ang II alone, of Ang II plus DuP 753 and of Ang II plus PD-123319, and the results are shown in Fig. 2. Ang II (ALPase activity $3 \cdot 70 \pm 0.19 \mu \mathrm{mol} / \mathrm{mg}$ protein per $30 \mathrm{~min})$ and Ang II plus PD-123319 $(4 \cdot 12 \pm 0.42 \mu \mathrm{mol} / \mathrm{mg}$ protein per $30 \mathrm{~min})$ reduced the activity of ALPase to approximately $60 \%$ of the basal level (6.70 $\pm 0.18 \mu \mathrm{mol} / \mathrm{mg}$ protein per $30 \mathrm{~min})$. DuP 753, a specific antagonist of $\mathrm{AT}_{1}$ receptors, overcame the inhibitory effects of Ang II $(5 \cdot 51 \pm 0 \cdot 51 \mu \mathrm{mol} / \mathrm{mg}$ protein per $30 \mathrm{~min}$ ). Addition of DuP 753 or PD-123319 alone to the culture medium had no effects on ALPase activity (data not shown). These results indicate that Ang II reduces the activity of ALPase in osteoblastic cells via the $A_{1}$ receptors.

\section{Effects of Ang II on the formation of mineralized nodules}

Figure $3 \mathrm{~A}$ shows the results of von Kossa staining of mineralized nodules that had been formed by osteoblastic cells during incubation for 14 days in medium supplemented with ascorbic acid and $\beta$-glycerophosphate in either the continuous presence or in the absence of $10^{-7}$ $M$ Ang II. Ang II inhibited the formation of mineralized nodules by osteoblastic cells. The nodules were quantified with an image analyzer and the number and total area of mineralized nodules were recorded. In the presence of Ang II at $10^{-7} \mathrm{M}$, about $50 \%$ of the control number of mineralized nodules were formed (Fig. 3B), and the total area of mineralized nodules was about $80 \%$ smaller than that in control (Fig. 3C). Parathyroid hormone (PTH) is known to activate adenylate cyclase and to induce increases in the concentration of intracellular cAMP in osteoblastic cells. In a recent study (Yamauchi et al. 1997) it was demonstrated that culture of osteoblastic cells with PTH resulted in the inhibition of differentiation and mineralization via production of cAMP. Therefore, we 


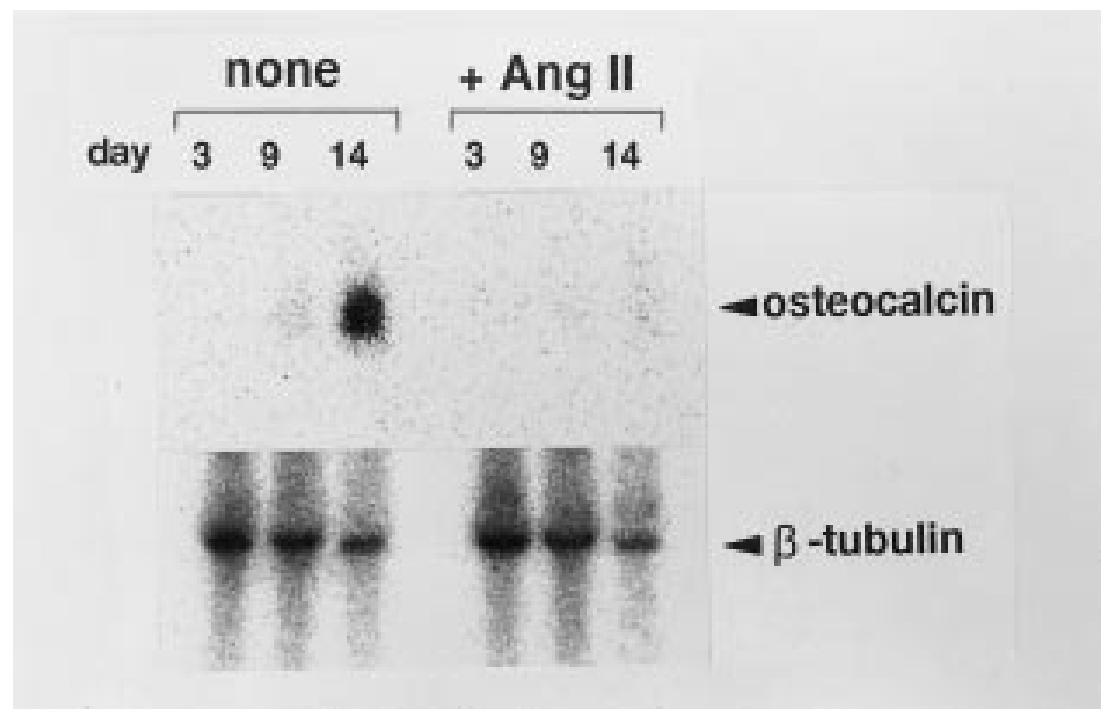

Figure 1 Northern blotting analysis of mRNA for osteocalcin in cultured osteoblastic cells. Total RNA was isolated from osteoblastic cells after treatment with $10^{-7} \mathrm{M}$ Ang II for 3, 9, and 14 days. Twenty micrograms of total RNA were subjected to electrophoresis in an agarose gel and were allowed to hybridize with ${ }^{32} \mathrm{P}$-labeled cDNA for rat osteocalcin or for $\beta$-tubulin. There were no appreciable changes in the level of mRNA for $\beta$-tubulin in cells assayed similarly on the same respective days.

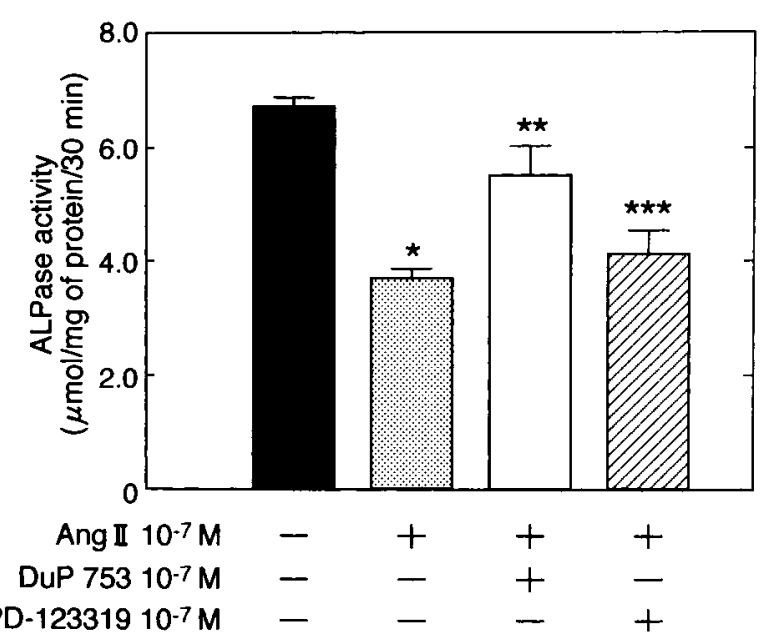

Figure 2 Activities of ALPase in osteoblastic cells treated with Ang II analog. Cells in 12-well plates were cultured for 9 days with $\alpha$-MEM that contained $10 \%$ fetal bovine serum, $5 \mathrm{mM}$

$\beta$-glycerophosphate, $50 \mu \mathrm{g} / \mathrm{ml}$ ascorbic acid, and $10^{-7} \mathrm{M}$ Ang II, $10^{-7} \mathrm{M}$ DuP 753 , and $10^{-7} \mathrm{M}$ PD-123319, as indicated. Data are means \pm S.D. of results from four wells. Results are representative of four experiments. ${ }^{*} P<0 \cdot 0001$ vs control; ${ }^{* * P}<0.005$ vs Ang II; ${ }^{* *} P<0 \cdot 001$ vs control.

used PTH as a control in our culture system. As anticipated, PTH at $10^{-7} \mathrm{M}$ strongly inhibited the formation of mineralized nodules (Fig. 3).

We next measured the accumulation of calcium in cells and the matrix layer in 12-well plates at day 14 (Fig. 4).
Ang II reduced the accumulation of calcium $(24 \cdot 8 \pm 3.9 \mu \mathrm{g}$ calcium/well $)$ compared with the control level $(38 \cdot 4 \pm 7 \cdot 8 \mu \mathrm{g}$ calcium/well). PTH also inhibited the formation of mineralized nodules in this culture system $(18 \cdot 2 \pm 1 \cdot 3 \mu \mathrm{g}$ calcium/well). These results suggest that Ang II reduced the rate of formation of mineralized nodules by osteoblastic cells.

The experiments described above indicated that Ang II might be involved in the differentiation of osteoblastic cells and in the formation of bone by these cells. 8-Br-cAMP inhibits both the differentiation of osteoblastic cells and the mineralization process (Inoue et al. 1995). Therefore, we attempted to identify the relevant subtype of angiotensin receptor and to quantitate the production of intracellular cAMP in our culture system.

\section{Identification of the relevant receptors for Ang II}

We examined the competitive displacement of ${ }^{125}$ I-Ang II by unlabeled Ang II, by DuP 753 (an antagonist specific for $\mathrm{AT}_{1}$ receptors) and by $\mathrm{PD}-123319$ (an antagonist specific for $\mathrm{AT}_{2}$ receptors) in an attempt to identify the specific binding sites for Ang II in the cells. As shown in Fig. 5A, unlabeled Ang II and DuP 753 completely prevented the binding of ${ }^{125}$ I-Ang II, while PD-123319 did not displace Ang II. The level of the receptors for Ang II reached a maximum on day 9 during an 18-day culture. To confirm the nature of the receptor subtype, we examined the capacity of angiotensin antagonists to compete with ${ }^{125}$ I-Ang II for binding sites (Fig. 5B). DuP 753 


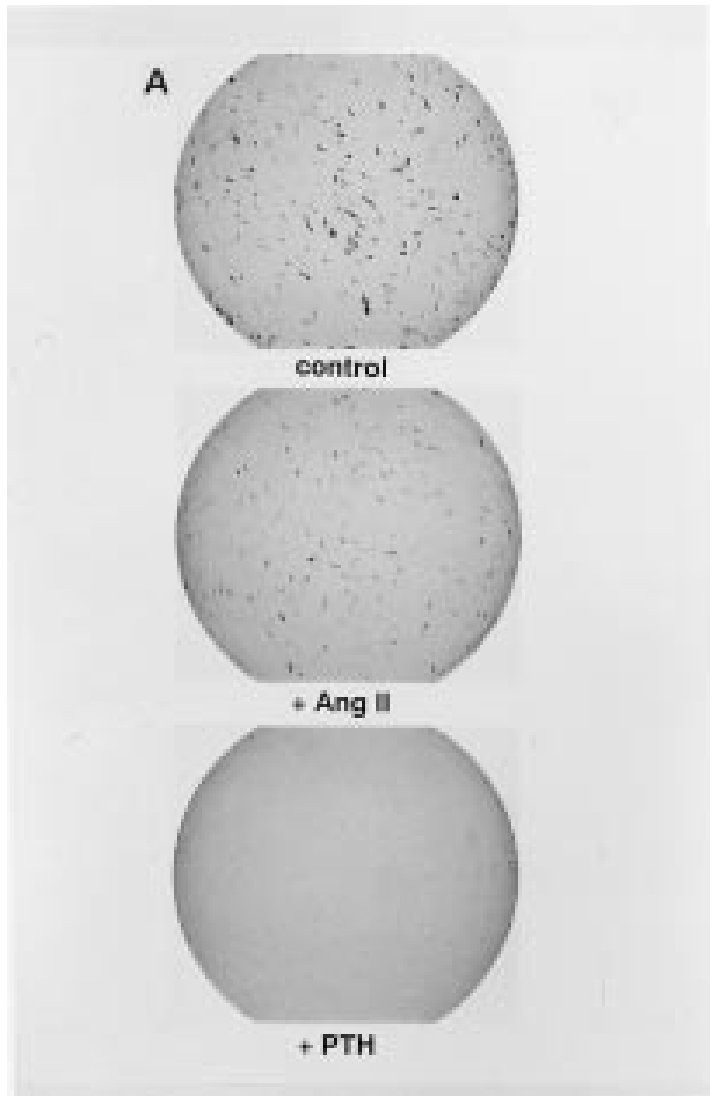

B

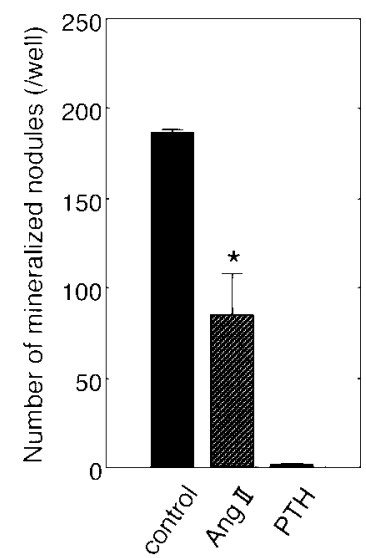

C

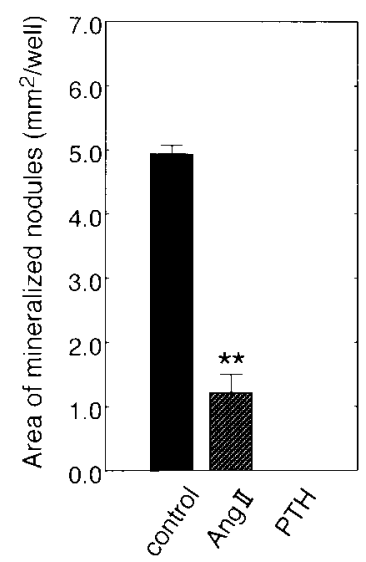

Figure 3 Phase-contrast photomicrographs of mineralized nodules in cultures of osteoblastic cells treated with Ang II (A) and the results of quantitative analysis (B and $\mathrm{C}$ ). Cells in 12-well plates were cultured for 14 days with $\alpha$-MEM that contained $10 \%$ fetal bovine serum, $5 \mathrm{mM} \beta$-glycerophosphate, $50 \mu \mathrm{g} / \mathrm{ml}$ ascorbic acid, and $10^{-7} \mathrm{M}$ Ang II or $10^{-7} \mathrm{M} \mathrm{PTH}$. Mineralized nodules were subjected to von Kossa staining as described in Materials and Methods. Numbers (B) and areas (C) of mineralized nodules were determined for four wells with the Mac SCOPE program. Data are means \pm S.D. of results from four wells and are representative of results from four experiments, which gave similar results. ${ }^{*} P<0.002$ vs control; ${ }^{* *} P<0 \cdot 00005$ vs control.

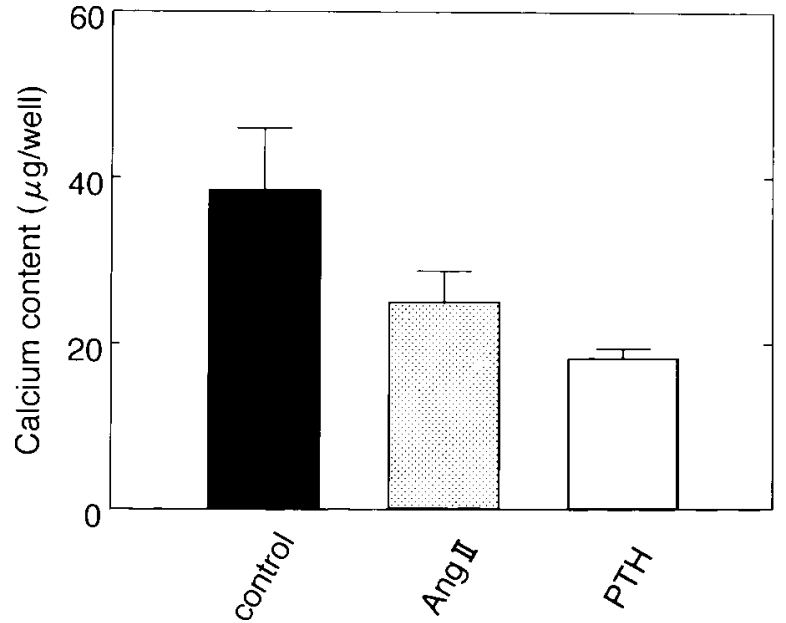

Figure 4 Inhibition of mineralization of osteoblastic cells in response to Ang II. Cells in 12-well plates were cultured for 14 days with $\alpha$-MEM that contained $10 \%$ fetal bovine serum, $5 \mathrm{mM}$ $\beta$-glycerophosphate, $50 \mu \mathrm{g} / \mathrm{ml}$ ascorbic acid, and $10^{-7} \mathrm{M}$ Ang II or $10^{-7} \mathrm{M} \mathrm{PTH}$, as indicated. Quantitative analysis of calcium ions derived from hydroxyapatite was performed. Data are means \pm S.D. of results from three wells. Data are representative of three experiments.

was less active than Ang II, and PD-123319 displaced the radiolabeled ligand only very weakly. These results indicated that most of the binding sites for ${ }^{125}$ I-Ang II corresponded to $\mathrm{AT}_{1}$ receptors. Scatchard plot analysis displayed a single component of binding sites with $3 \cdot 2 \mathrm{fmol} / 10^{6}$ cells. We have also obtained preliminary results that cloned rat osteoblastic cells, $\mathrm{ROB}-\mathrm{C} 8 \mathrm{a}$, and cloned mouse pluripotent cells, C3H10T1/2, express angiotensin II receptors (data not shown).

\section{Production of cAMP in response to Ang II}

Our final experiments were designed to determine whether Ang II could induce the activity of adenylate cyclase in this culture system. Figure 6A shows that Ang II caused an increase in the level of intracellular cAMP in cultures in a dose-dependent manner. The maximal level (70 pmol $/ 10^{6}$ cells), corresponding to the maximum activity of adenylate cyclase, was found on day 9. As shown in Fig. 6B, the stimulation of the formation of intracellular cAMP by $10^{-7} \mathrm{M}$ Ang II was abolished by preincubation of cells for $15 \mathrm{~min}$ with $10 \mu \mathrm{M}$ DuP 753, while preincubation with $10 \mu \mathrm{M}$ PD-123319 barely affected the stimulatory effect of Ang II. These results indicate that the production of intracellular cAMP is promoted through the $\mathrm{AT}_{1}$ receptor in response to Ang II.

\section{Discussion}

In this study, we showed that Ang II is a potent suppressor of the differentiation of osteoblastic cells from newborn rat 

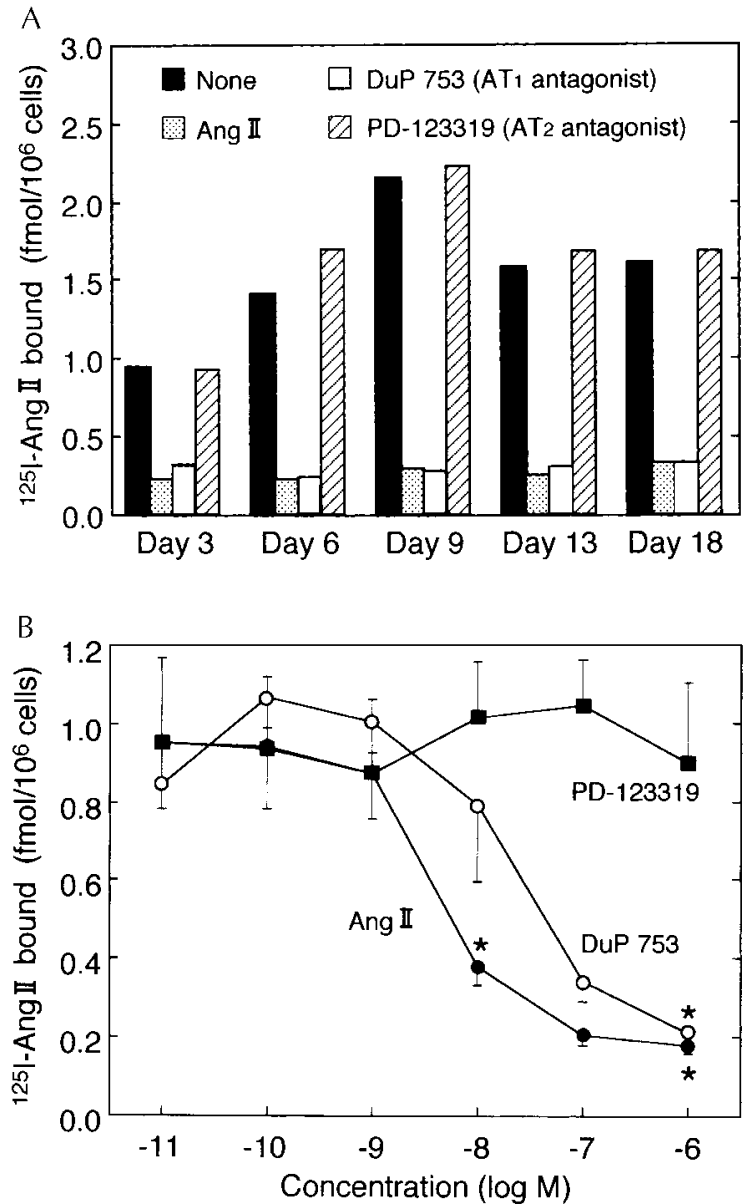

Figure 5 Identification of the subtype of angiotensin receptor. Cells in 12-well plates were cultured with $\alpha$-MEM that contained $10 \%$ fetal bovine serum, $5 \mathrm{mM} \beta$-glycerophosphate, and $50 \mu \mathrm{g} / \mathrm{ml}$ ascorbic acid. The cells were incubated at $4{ }^{\circ} \mathrm{C}$ for $1 \mathrm{~h}$ with

${ }^{125}$ I-Ang II $(920 \mathrm{~Bq})$ in the presence or in the absence of unlabeled Ang II, DuP 753 or PD-123319 at various concentrations. (A) The expression of receptor subtypes during the 18-day culture period. Values represent the means of results from two wells. Data are representative of three separate experiments, which gave similar results. (B) Ligand specificity. Cells on day 9 were used in this experiment. Each value is the mean \pm S.D. of results of triplicate determinations. ${ }^{*} P<0 \cdot 001 \mathrm{vs}$ control.

calvariae and of the formation of bone by these cells. Ang II was found to decrease the level of mRNA for osteocalcin, which is a well known marker of osteoblastic differentiation. The activity of ALPase was also reduced by the addition of Ang II to the culture medium. Moreover, Ang II decreased the rate of formation of mineralized nodules (a model of bone formation in vitro) and the precipitation of calcium by osteoblastic cells. The present results provide evidence that Ang II decelerates the differentiation and mineralization of osteoblastic cells in this culture system.

As described above, Ang II acted to influence the differentiation and mineralization of osteoblastic cells from

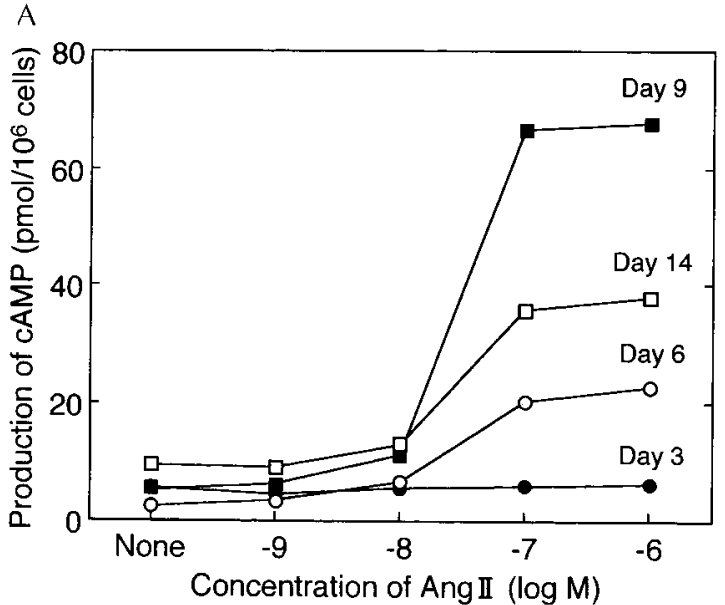

B

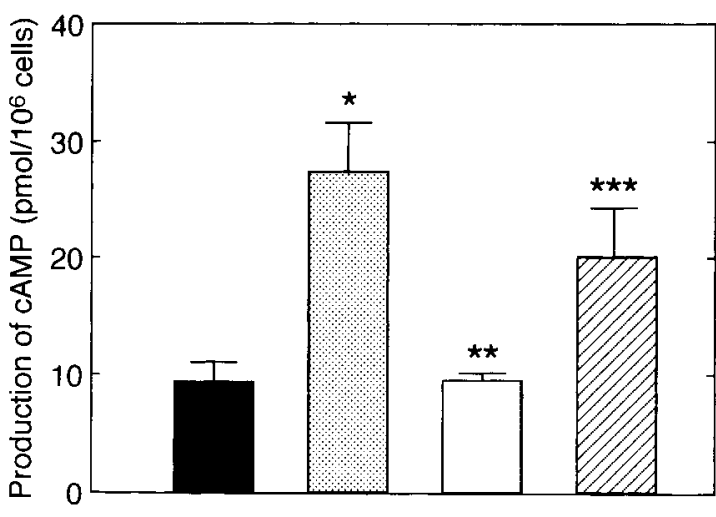

$$
\begin{array}{rrrrr}
\text { Ang II } 10^{-7} \mathrm{M} & - & + & + & + \\
\text { DuP 753 10-5 M } & - & - & + & - \\
\text { PD-123319 10-5 M } & - & - & - & +
\end{array}
$$

Figure 6 The Ang II-induced accumulation of intracellular cAMP. Cells in 12-well plates were exposed to Ang II at increasing concentrations for $15 \mathrm{~min}$ at $37^{\circ} \mathrm{C}$ in the presence of $0.5 \mathrm{mM}$ 3 -isobutyl-1-methylxanthine and then intracellular levels of cAMP determined. (A) The production of intracellular cAMP, as determined at the indicated times during the 14-day culture period. Values represent the means of results from two wells and results are representative of three experiments. (B) The effects of subtype-specific antagonists on the production of cAMP. Cells on day 9 were used in this experiment. Each value is the mean \pm S.D. of results of four determinations. ${ }^{*} P<0.001$ vs control; ${ }^{* *} P<0.002$ vs Ang II; ${ }^{* *} P<0 \cdot 01$ vs control.

rat calvariae. We postulated that cAMP might be a candidate factor for a second messenger of Ang II, since we had demonstrated previously that 8-Br-cAMP (Inoue et al. 1995) and endothelins (Hagiwara et al. 1996), which induce production of intracellular cAMP, reduced the rate of mineralization by osteoblastic cells. We confirmed that continuous culture of cells with PTH decreased the rate of formation of mineralized nodules in our culture system 
(Figs. 3 and 4). PTH has been reported to inhibit the activity of ALPase and the formation of mineralized nodules by osteoblastic cells via its effect on the production of cAMP (Yamauchi et al. 1997). Furthermore, we identified the role of the $\mathrm{AT}_{1}$ receptor (Fig. 5) and the capacity of osteoblastic cells to produce cAMP (Fig. 6) in our culture system. In many tissues, Ang II decreases the rate of production of cAMP by inhibiting adenylate cyclase via Gi protein. However, recent studies have demonstrated that Ang II stimulates the accumulation of cAMP in rat adrenal glomerular cells (Missale et al. 1989), rat fetal skin (Johnson \& Aguilera 1991), and bovine adrenocortical cells (Rainey et al. 1991). At present there is little evidence to support any direct coupling of the $\mathrm{AT}_{1}$ receptor to a $\mathrm{G}$ protein(s) that activates adenylate cyclase. Stimulation of the production of cAMP by Ang II might be expected to involve activation of type I adenylate cyclase, one of the isoforms of adenylate cyclase, by protein kinase $\mathrm{C}$ and/or $\mathrm{Ca}^{2+} /$ calmodulin or via an indirect mechanism involving the generation of prostaglandin (Rainey et al. 1991). Cell populations enzymatically isolated from newborn rat calvariae are heterogenous. In future, therefore, we must identify the cells that express the $\mathrm{AT}_{1}$ receptor or adenylate cyclase by in situ hybridization. We also showed that Ang II stimulates the production of inositol 1,4,5trisphosphate in this culture system (Hiruma et al. 1997). Accumulation of intracellular calcium may be involved in the regulation of osteoblastic metabolism.

Stein et al. (1990) provided a model for the reciprocal relationship between cell proliferation and the expression of differentiation-related genes. They proposed that cell proliferation is inhibited before events that are associated with the differentiation of osteoblastic cells can occur. We reported previously that cGMP, produced in response to natriuretic peptides, inhibited the proliferation and promoted the differentiation of osteoblastic cells (Hagiwara et al. 1996). A recent study in our laboratory demonstrated that Ang II might stimulate the synthesis of DNA via the activation of mitogen-activated protein kinases in our culture system (Hiruma et al. 1997). We showed here that Ang II seems to decelerate the differentiation and mineralization of osteoblastic cells. Thus, the effects of Ang II might support the model proposed for the process of bone formation.

A single heterozygous nucleotide substitution (a mutation encoding a change from His to Arg at position 223) in an exon of the gene for the PTH-PTH-related peptide receptor was identified recently in a patient with Jansentype metaphyseal chondrodysplasia, a rare form of shortlimbed dwarfism (Schipani et al. 1995). This mutation was associated with an increase in the basal level of cAMP and a decrease in the rate of production of cAMP in response to PTH. These observations suggest that the accumulation of cAMP might be involved in the abnormal proliferation and differentiation of growth-plate chondrocytes and bone cells. Moreover, there are some reports that ACE inhibitors, such as captopril and enalapril, might have caused severely underdeveloped calvarial bone in human fetuses (Mehta \& Modt 1989, Barr \& Cohen 1991). To date, little information is available on the relationship between Ang II and osteoblastic metabolism. However, our present observations support the hypothesis that Ang II might be involved in osteogenesis via the $\mathrm{AT}_{1}$ receptor.

In cultures of mouse bone marrow, $\mathrm{C}$-type natriuretic peptide (CNP) increased the rate of bone resorption (Holliday et al. 1995). Those authors proposed that CNP might be a potent activator of osteoclast activity. Endothelin also interacts specifically with osteoclasts to inhibit osteoblastic bone resorption (Alam et al. 1992). Endothelins have been demonstrated to cause a reduction in ALPase activity in calvarial osteoblastic cells (Takuwa et al. 1989, 1990). We also reported that natriuretic peptides (atrial natriuretic peptide and CNP) promoted the differentiation of and formation of bone by calvarial osteoblastic cells (Hagiwara et al. 1996) and osteoblastic MC3T3-E1 cells (Inoue et al. 1996) and that endothelin suppressed these processes (Hagiwara et al. 1996). In the present study, we obtained evidence that Ang II might decelerate these processes. Bone is rich in blood vessels and bone formation requires vascularization. These observations suggest that certain relationships are likely to exist between bone cells and vasoactive peptides in the local environment. It does not seem inappropriate to propose that vasoactive peptides, including Ang II, natriuretic peptides, and endothelins, might be novel local regulators of bone remodeling.

\section{Acknowledgements}

The authors thank Dr Hitoshi Miyazaki (Tsukuba University, Japan) for helpful discussions, Mrs Kazuko Tanaka for culturing cells, and Mrs Setsuko Satoh for secretarial assistance. This work was supported by Grants-in-Aid for Scientific Research from the Ministry of Education, Science, Sports, and Culture of Japan and by grants from the Kowa Life Science Foundation, and the Naito Foundation.

\section{References}

Aceto JF \& Baker KM 1990 [Sar ${ }^{1}$ ]angiotensin II receptor-mediated stimulation of protein synthesis in chick heart cells. American Journal of Physiology 258 H806-H813.

Alam ASMT, Gallagher A, Shankar V, Ghatei MA, Datta HK, Huang CLH, Moonga BS, Chambers TJ, Bloom SR \& Zaidi M 1992 Endothelin inhibits osteoclastic bone resorption by a direct effect on cell motility: implications for the vascular control of bone resorption. Endocrinology 130 3617-3624.

Antosz ME, Bellows CG \& Aubin JE 1989 Effects of TGF-B and EGF on cell proliferation and the formation of bone nodules in isolated foetal rat calvaria cells. Journal of Cell Physiology 140 386-395.

Baker J, Liu JP, Robertson EJ \& Efstratiadis A 1993 Role of insulinlike growth factors in embryonic and postnatal growth. Cell $\mathbf{7 5}$ 73-82. 
Barr MJ \& Cohen MMJ 1991 ACE inhibitor fetopathy and hypocalvaria: the kidney-skull connection. Teratology 44 485-495.

Bellows CG, Heersche JNM \& Aubin JE 1990 Determination of the capacity for proliferation and differentiation of osteoprogenitor cells in the presence and absence of dexamethasone. Developmental Biology 140 132-138.

Chomczynski P \& Sacchi N 1987 Single-step method of RNA isolation by acid guanidinium thiocyanate-phenol-chloroform extraction. Analytical Biochemistry 162 156-159.

Deng C, Wynshaw-Boris A, Zhou F, Kuo A \& Leder P 1996 Fibroblast growth factor receptor 3 is a negative regulator of bone growth. Cell 84 911-921.

Hagiwara H, Inoue A, Yamaguchi A, Yokose S, Furuya M, Tanaka S \& Hirose S 1996 cGMP produced in response to ANP and CNP regulates proliferation and differentiation of osteoblastic cells. American Journal of Physiology 270 C1311-C1318.

Harris SE, Bonewald LF, Harris MA, Sabatini M, Dallas S, Feng JQ, Ghosh-Choudhury N, Wozney J \& Mundy GR 1994 Effects of transforming growth factor $\beta$ on bone nodule formation and expression of bone morphogenetic protein 2 , osteocalcin, osteopontin, alkaline phosphatase, and type I collagen mRNA in long-term cultures of fetal rat calvarial osteoblasts. Journal of Bone and Mineral Research 9 855-863.

Hiruma Y, Inoue A, Hirose S \& Hagiwara H 1997 Angiotensin II stimulates the proliferation of osteoblast-rich populations of cells from rat calvariae. Biochemical and Biophysical Research Communications 230 176-178.

Holliday LS, Dean AD, Greenwald JE \& Gluck SL 1995 C-type natriuretic peptide increases bone resorption in 1,25-dihydroxyvitamin $\mathrm{D}_{3}$-stimulated mouse bone marrow cultures. Journal of Cellular Biochemistry 270 18983-18989.

Inoue A, Hiruma Y, Hirose S, Yamaguchi A \& Hagiwara H 1995 Reciprocal regulation by cyclic nucleotides of the differentiation of rat osteoblast-like cells and mineralization of nodules. Biochemical and Biophysical Research Communications 215 1104-1110.

Inoue A, Hiruma Y, Hirose S, Yamaguchi A, Furuya M, Tanaka S \& Hagiwara H 1996 Stimulation by C-type natriuretic peptide of the differentiation of clonal osteoblastic MC3T3-E1 cells. Biochemical and Biophysical Research Communications 221 703-707.

Johnson MC \& Aguilera G 1991 Angiotensin-II receptor subtypes and coupling to signaling systems in cultured fetal fibroblasts. Endocrinology 129 1266-1274.

Liu JP, Baker J, Perkins AS, Robertson EJ \& Efstratiadis A 1993 Mice carrying null mutations of the genes encoding insulin-like growth factor I (Igf-1) and type 1 IGF receptor (Igf1r). Cell 75 59-72.

Lowry OH, Roberts NR, Wu ML, Hixon WS \& Crawford EJ 1954 The quantitative histochemistry of brain. II. Enzyme measurements. Journal of Cellular Biochemistry 207 19-37.

Mehta N \& Modt N 1989 ACE inhibitors in pregnancy. Lancet ii 96.
Millan MA, Jacobowitz DM, Aguilera G \& Catt KJ 1991 Differential distribution of $\mathrm{AT}_{1}$ and $\mathrm{AT}_{2}$ angiotensin II receptor subtypes in the rat brain during development. Proceedings of the National Academy of Sciences of the USA 88 11440-11444.

Missale C, Memo M, Sigala S, Carruba MO \& Spano P 1989 Angiotensin II differentially affects cyclic AMP formation in intact adrenal glomerulosa cells and in purified membrane preparations. Regulatory Peptides 24 167-178.

Phillips MI 1987 Functions of angiotensin in the central nervous system. Annual Review of Physiology 49 413-435.

Rainey WE, Byrd EW, Sinnokrot RA \& Carr BR 1991 Angiotensin-II activation of cAMP and corticosterone production in bovine adrenocortical cells: effects of nonpeptide angiotensin-II antagonists. Molecular and Cellular Endocrinology 81 33-41.

Schipani E, Kruse K \& Juppner H 1995 A constitutively active mutant PTH-PTHrP receptor in Jansen-type metaphyseal chondrodysplasia. Science 268 98-100.

Steckelings UM, Bottari SP \& Unger T 1992 Angiotensin receptor subtypes in the brain. Trends in Pharmacological Sciences 13 365-368.

Stein GS, Lian JB \& Owen TA 1990 Relationship of cell growth to the regulation of tissue-specific gene expression during osteoblast differentiation. FASEB Journal 4 3111-3123.

Takuwa Y, Ohue Y, Takuwa N \& Yamashita K 1989 Endothelin-1 activates phospholipase $\mathrm{C}$ and mobilizes $\mathrm{Ca}^{2+}$ from extra- and intracellular pools in osteoblastic cells. American Journal of Physiology 257 E797-E803.

Takuwa Y, Masaki T \& Yamashita K 1990 The effects of the endothelin family peptides on cultured osteoblastic cells from rat calvariae. Biochemical and Biophysical Research Communications 170 998-1005.

Wong MM, Rao LG, Ly H, Hamilton L, Tong J, Sturtridge W, McBroom R, Aubin JE \& Murray TM 1990 Long-term effects of physiologic concentrations of dexamethasone on human bonederived cells. Journal of Bone and Mineral Research 5 803-813.

Yamaguchi A, Katagiri T, Ikeda T, Wozney JM, Rosen V, Wang EA, Kahn AJ, Suda T \& Yoshiki S 1991 Recombinant human bone morphogenetic protein-2 stimulates osteoblastic maturation and inhibits myogenic differentiation in vitro. Journal of Cell Biology 113 681-687.

Yamauchi N, Nishikawa S, Kido J, Ohishi K, Nagata T, Kataoka M, Shinohara H \& Ishida H 1997 Relationship between the expression of parathyroid hormone receptors and hormonal effect during rat osteoprogenitor cell differentiation. Journal of Bone and Mineral Metabolism 15 17-22.

Received 21 July 1997

Accepted 15 October 1997 